\title{
PELATIHAN PEMBUATAN KERAJINAN TANGAN GELANG TALIKUR DENGAN PEMANFAATAN LIMBAH SEPATU PADA ANAK SEKOLAH DASAR DI DESA KUTAMBEKAR KARAWANG
}

\author{
${ }^{1}$ Sinta Maria Dewi, ${ }^{2}$ Ayu Fitri, ${ }^{3}$ Yulistina Nur DS \\ PGSD Fakultas Keguruan dan Ilmu Pendidikan \\ Universitas Buana Perjuangan \\ sintamaria@ubpkarawang.ac.id \\ ayufitri@ubpkarawang.ac.id \\ yulistina.nur@ubpkarawang.ac.id
}

\begin{abstract}
Community service activities are one form of the implementation of Tri Dharma Perguruan Tinggi which has the aim that the lecturers and students of the Elementary School Teacher Education Study Program have community skills. The target of this service is students in Kutamekar Village, Ciampel District, Karawang. This activity was held on 12 August 2017. This service activity was packaged in the form of training activities. After being given the material, then they were guided to make crafts from shoelaces to make talikur bracelets. From community service activities, results and benefits were obtained including increasing the knowledge of students about making craft skills to make talikur bracelets.
\end{abstract}

Keywords: Handicraft Making Training, Gelang Talikur, Elementary Students

\begin{abstract}
Abstrak : Kegiatan pengabdian pada masyarakat adalah salah satu bentuk penyelenggaraan Tri Dharma Perguruan Tinggi yang memiliki tujuan agar dosen dan mahasiswa Program Studi Pendidikan Guru Sekolah Dasar mempunyai keterampilan bermasyarakat. Sasaran dari pengabdian ini adalah siswa/siswi di Desa Kutamekar Kecamatan Ciampel Karawang. Kegiatan ini dilaksanakan pada tanggal 12 Agustus 2017. Kegiatan pengabdian ini dikemas dalam bentuk kegiatan pelatihan. Setelah diberi materi, selanjutnya mereka dibimbing untuk membuat kerajina dari tali sepatu untuk membuat gelang talikur. Dari kegiatan pengabdian masyarakat, diperoleh hasil dan manfaat diantaranya adalah meningkatnya pengetahuan siswa-siswa tentang keterampilan membuat kerajinan tangan membuat gelang talikur.
\end{abstract}

Kata Kunci : Pelatihan Pembuatan Kerajinan Tangan, Gelang Talikur, Siswa SD Pendahuluan 
Pendidikan merupakan salah satu elemen penting dalam kemajuan suatu bangsa. Bangsa yang ingin maju haruslah memajukan pendidikannya terlebih dahulu. Karena melalui pendidikan seseorang dapat memperoleh ilmu, pengetahuan dan keterampilan guna meningkatkan kemampuan berfikir, berusaha, dan penguasaan teknologi. Sehingga diharapkan ia dapat memenuhi segala kebutuhan dengan segala keterampilan yang dimilikinya.

Penyelenggaraan pendidikan disekolah yang melibatkan guru sebagai pendidik dan siswa sebagai peserta didik, diwujudkan dengan adanya interaksi belajar mengajar atau proses pembelajaran. Dalam konteks pembelajaran ini, guru dengan sadar merencanakan kegiatan pengajarannya secara sistematis dan berpedoman pada seperangkatan aturan dan rencana tentang pendidikan yang dikemas dalam bentuk kurikulum. Dalam perkembangan teknologi dan kemajuan jaman yang terus berlangsung, maka bangsa Indonesia memerlukan sumber daya manusia yang mempunyai potensi, yaitu manusia yang mandiri, cerdas dan terampil. Pendidikan sangat dibutuhkan untuk menghasilkan sumber daya manusia yang demikian.

Mulyasa (2006) bahwa guru memegang peranan yang penting dalam perencanaan maupun pelaksanaan pembelajaran. Menyadari hal tersebut, betapa pentingnya untuk meningkatkan aktifitas, kreativitas, kualitas dan profesionalisme guru yang mampu menciptakan pembelajaran kreatif,inovatif dan menyenangkan.

Pembelajaran merupakan padanan dari kata dalam bahasa inggris instruction, yang berarti membuat orang belajar. Tujuannya ialah membantu orang belajar atau memanipulasi (merekayasa) lingkungan sehingga kemudahan bagi orang yang belajar. Menurut Himatun Nafiah (2012:20) Keterampilan pada anak usia sekolah merupakan usaha untuk memperoleh kompetensi cekat, cepat dan tepat dalam menghadapi permasalahan belajar. Dalam hal ini, pembelajaran Keterampilan dirancang sebagai proses komunikasi belajar untuk mengubah perilaku siswa menjadi cekat, cepat dan tepat melalui pembelajaran kerajinan dan teknologi rekayasa dan teknologi pengolahan. Perilaku terampil ini dibutuhkan dalam keterampilan hidup manusia di masyarakat.

Jadi pembelajaran keterampilan adalah pembelajaran sebagai suatu rangkaian event (kejadian, peristiwa, kondisi dan lain-lain) yang secara sengaja dirancang untuk 
mempengaruhi murid, sehingga proses belajarnya dapat berlangsung dengan mudah dan murid menjadi cekat, cepat dan tepat dalam teknologi rekayasa. Dalam kaitannya dengan pembelajaran di SD membuat gelang talikur yaitu kegiatan berlatih berkarya senirupa yang dilakukan dengan cara membuat gelang dari bahan limbah tali sesuai dengan tingkat kemampuan anak. Zimmerer (dalam Kasmier:2006) mengartikan kewirausahaan sebagai suatu proses penerapan kreativitas dan inovasi dalam memecahkan persoalan dan menemukan peluang untuk memperbaiki kehidupan (usaha). Seorang wirausahawan adalah individu-individu yang berorientasi kepada tindakan, dan memiliki motivasi tinggi, yang berisiko dalam mengejar tujuannya. Untuk dapat mencapai tujuan-tujuannya, maka diperlukan sikap dan perilaku yang mendukung pada diri seorang wirausahawan. Sikap dan perilaku sangat dipengaruhi oleh sifat dan watak yang dimiliki oleh seseorang. Sifat dan watak yang baik, berorientasi pada kemajuan dan positif merupakan sifat dan watak yang dibutuhkan oleh seorang wirausahawan agar wirausahawan tersebut dapat maju/sukses. Untuk itu motivasi (sikap dan perilaku) semangat kewirausahaan perlu dipupuk. Akan tetapi upaya menumbuhkan semangat kewirausahaan ternyata tidak mudah. Bagi sebagian orang, motivasi kewirausahaan merupakan hadiah (given) dan bagi sebagian orang lainnya perlu perjuangan untuk menumbuhkan.

Berdasarkan latar belakang di atas, perlu diadakannya pembelajaran pembuatan keterampilan gelang talikur kepada siswa sekolah dasar tentunya dengan konsep pembelajaran yang berbeda yang akan dilakukan diluar sekolah yaitu di Hutan Kertas Desa Kutamekar Kecamatan Ciampel Karawang. Selain menambah wawasan dan keterampilan kepada siswa juga dengan suasana yang berbeda bisa menumbuhkan semangat belajar khususnya membuat keterampilan dari gelang talikur.

\section{Metode}

Permasalahan siswa-siswi SDN Kutamekar I Kecamatan Ciampel Kabupaten Karawang masih kurang dalam pengetahuan memanfaatkan limbah serta membuat kerajinan tangan. Kegiatan ini dikemas dalam bentuk pelatihan pembuatan kerajinan tangan gelang talikur dengan tempat di alam bebas yaitu di Hutan Kertas. 
Setelah diberi pembelajaran, selanjutnya mereka dibimbing untuk membuat gelang tali kur, dan hasil kerajinan tangan dipasarkan secara lokal dilingkungan sekolah.

\section{Langkah-langkah Kegiatan}

Berikut ini adalah langkah-langkah pembelajaran yang dilakukan:

\section{Tahap Persiapan}

Tahap persiapan yang dilakukan meliputi:

a. Survey

b. Pemantapan dan penentuan lokasi dan sasaran

Penyusunan bahan/ materi penyuluhan, yang meliputi: Pemanfaatan Limbah dengan Membuat Gelang Tali Kur

\section{Tahap Pelaksanaan Pelatihan}

Tahap pelaksanaan pelatihan dilakukan persiapan. Dalam tahapan ini dilakukan pertama, penjelasan tentang Pemanfaatan Limbah, sesi ini menitikberatkan pada penjelasan mengenai macam-macam limbah yang bisa di olah menjadi barang yang berguna. Kedua, sesi pembelajaran yang menitikberatkan pada materi Bagaimana cara membuat gelang tali kur. Ketiga, sesi pembelajaran yang menitikberatkan pada pembuatan atau praktik membuat gelang tali kur bersama dengan anak sekolah dasar. Adapun slangkah-langkah pembuatanyaebagai berikut

\section{Langkah 1}

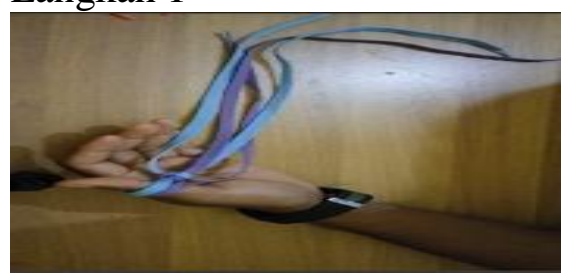

Siapkan tali sepatu sebanyak 2 buah

\section{Langkah 2}

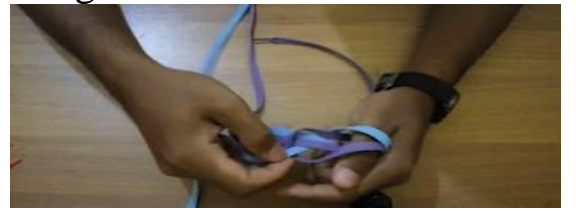


Setelah tali sepatu sudah siap, ikatkan pada jari jempol yang bertujuan untuk sebagai lubang untuk mengikat gelang.

\section{Langkah 3}
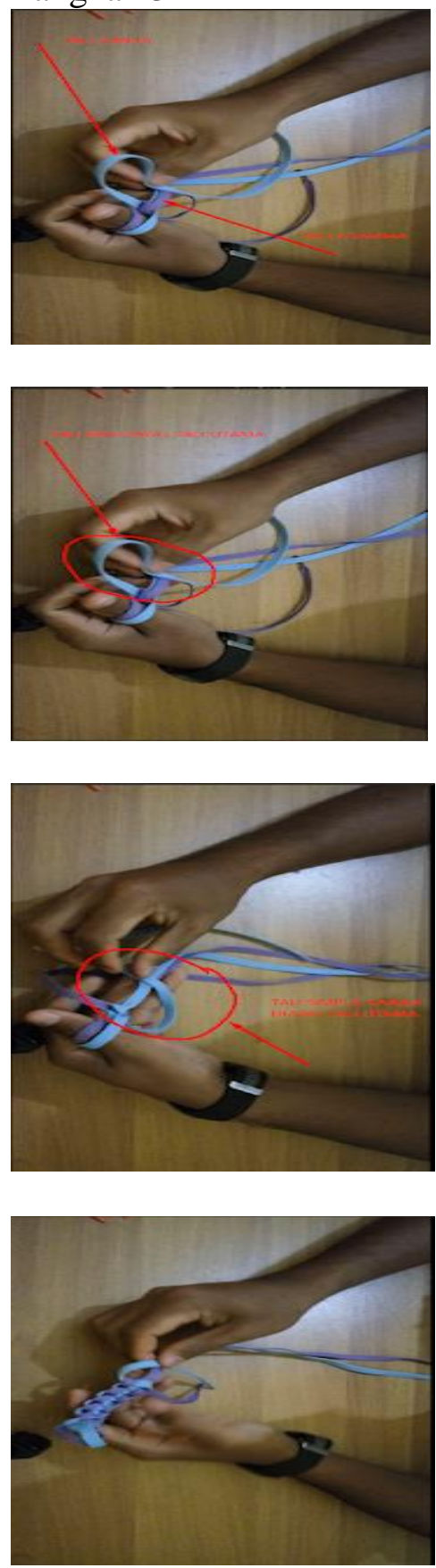

Buat ikatan atau simpul untuk membuat gelang. Yang diperhatikan saat membuat simpul adalah posisi tali untuk simpul harus berada diatas tali utama secara bergilir, misalnya simpul pertama tali simpul kiri yang berada di atas, simpul kedua berarti tali kiri yang berada diatas tali utama. Terus ulang sampai tali untuk simpul habis. 


\section{Langkah 4}

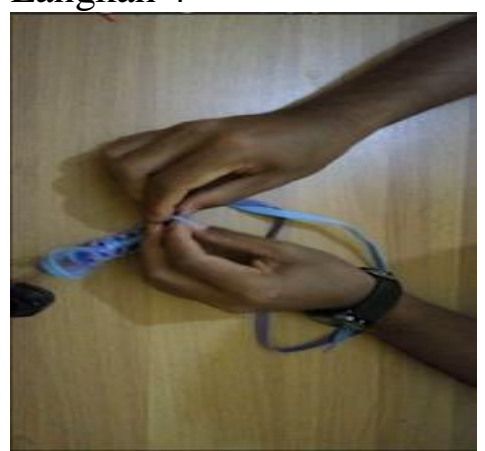

Hasil Akhir Gelang

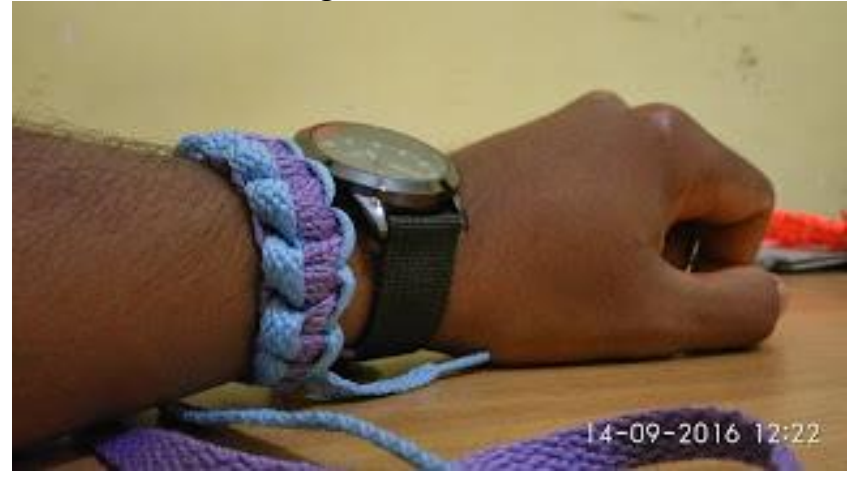

\section{Hasil dan Pembasahan}

Permasalahan siswa-siswi SDN Kutamekar I Kecamatan Ciampel Kabupaten Karawang masih kurang dalam pengetahuan memanfaatkan limbah yang bersifat ekonomis melalu pembuatan kerajinan tangan.

Kegiatan pelatihan ini bertujuan meningkatkan pengetahuan tentang pemanfaatan limbah di Kecamatan Ciampel Karawang, dan dilaksanakan pada bulan Agustus 2018. Kegiatan pelatihan berjalan dengan lancar yang dilakukan oleh 20 siswa dari beberapa sekolah yang ada di desa Kutamekar. Peserta pelatihan terlihat antusias dan termotivasi dengan pembuatan kerajinan tangan membuat gelang talikur. Ini bisa terlihat dari awal acara pelatihan sampai akhir acara, semua siswa mengikuti pelatihan dengan baik dan lancar. 
Materi yang diberikan dalam plelatihan adalah tentang pemanfaatan limbah sepatu (tali sepatu) dan pembuatan kerajinan tangan gelang talikur dalam mengoptimalkan perkembangan motorik kasar anak khususnya anak sekolah dasar.

Kegiatan pertama pelatihan diberikan materi pemanfaatan limbah. Pelatihan dilakukan dengan menggunakan beberapa macam limbah sepatu. Kemudian dilakukan sesi tanya jawab kepada siswa-siswi tentang materi yang telah diberikan. Kegiatan kedua pelatihan, siswa-siswa diajarkan membuat gelang talikur dari limbah sepatu. Berdasarkan hasil kegiatan dapat dilihat hasilnya yaitu siswa-siswa pada saat mempraktikan untuk membuat kerajinan tangan gelang talikur, terlihat banyak siswa yang paham mengenai pemabfaatan limbah dan terampil dalam membuat kerajinan tangan talikur dan bisa dikatakan $90 \%$ berhasil.

\section{Simpulan}

Berdasarkan hasil pelaksanaan kegiatan pengabdian pada masyarakat, maka dapat disimpulkan bahwa kegiatan "Pelatihan Pembuatan Kerajinan Tangan Gelang Talikur dengan Pemanfaatan Limbah Sepatu pada Anak Sekolah Dasar di Desa Kutamekar Karawang" dapat dilaksanakan dengan baik dan lancar. Pelatihan dilakukan selama 1 hari dan dihadiri 20 siswa sebagai peserta pelatihan. Sekitar 90\% yaitu 18 siswa dapat memahami tentang pemanfaatan limbah dan membuat kerajinana tangan gelang talikur.

Pelatihan dialkukan dengan memberi materi tentang pemanfaatan limbah. Pelatihan dilakukan dengan menggunakan beberapa macam limbah sepatu. Kemudian dilakukan sesi tanya jawab kepada siswa-siswi tentang materi yang telah diberikan. Selanjutnya siswa-siswa diajarkan membuat gelang talikur dari limbah sepatu. Berdasarkan hasil kegiatan dapat dilihat hasilnya yaitu siswa-siswa pada saat mempraktikan untuk membuat kerajinan tangan gelang talikur, terlihat banyak siswa yang paham mengenai pemabfaatan limbah dan terampil dalam membuat kerajinan tangan talikur dan bisa dikatakan $90 \%$ berhasil. 